

\title{
GEOCHEMISTRY AND CLAY MINERALS OF SURFACE SEDIMENTS OF SOUTHWESTERN JOHOR, MALAYSIA
}

\author{
(Geokimia dan Mineral-mineral Liat Enapan Permukaan di Barat Daya Johor, Malaysia) \\ Hasrizal Shaari ${ }^{1,2 *}$, Noor Azhar Mohd Shazili ${ }^{2}$, Lina Idayu Abdullah ${ }^{1}$, Nor Antonina Abdullah ${ }^{1}$, \\ Mohd Lokman Husain ${ }^{1}$, Norhayati Md. Tahir ${ }^{1}$ \\ ${ }^{1}$ School of Marine and Environmental Science \\ ${ }^{2}$ Institute of Oceanography and Environment \\ Universiti Malaysia Terengganu, 21030 Kuala Terengganu, Terengganu, Malaysia \\ *Corresponding author: riz@umt.edu.my
}

Received: 19 December 2016; Accepted: 18 February 2017

\begin{abstract}
Surface sediments from tropical coastal settings of Southwestern Johor, Malaysia, were analyzed for grain size, major element content and clay minerals using particle size analyzer, scanning electron microscope-energy dispersive spectrometer (SEM-EDS) and X-ray Diffractometer (XRD). This work is aimed at investigating the geochemical composition of surface sediments and possible anthropogenic inputs from urban settlements. Sediment texture was found to be clayey with an average of $45.15 \%$. The abundance of major elements in decreasing order is $\mathrm{SiO}_{2}>\mathrm{Al}_{2} \mathrm{O}_{3}>\mathrm{K}_{2} \mathrm{O} \geq \mathrm{ClO}_{2} \geq \mathrm{Na}_{2} \mathrm{O}>\mathrm{MgO}>\mathrm{MnO}>\mathrm{ZnO}$. The dominance of $\mathrm{SiO}_{2}$ appears to be linked with the draining of Sungai Pulai to the study area. The concentration of $\mathrm{ZnO}$ registered a hundred times higher than the average natural level of zinc in the earth's crust. Higher levels of $\mathrm{Zn}$ might be derived from the combination of anthropogenic input and natural geochemical processes. Mineral abundance follows the order of quartz $>$ kaolinite $>$ muscovite $>$ smectite $>$ calcite $>$ illite. Smectite was detected in the upper river sediment, but was not present in the estuarine sediment. This is likely due to the accumulation and intensity of weathering products. The dominance of quartz in the coastal sediments is due to the intense weathering process.
\end{abstract}

Keywords: tropical, sediments, elements, clay minerals, Malaysia

\begin{abstract}
Abstrak
Sedimen permukaan dari pesisiran pantai tropika di Barat Daya Johor, Malaysia, telah dianalisis untuk saiz butiran, kandungan unsur utama dan mineral liat dengan menggunakan penganalisa saiz partikal, imbasan elektron mikroskop-spektrometer serakan tenaga (SEM-EDS) and pembelauan sinaran-X (XRD). Kajian ini bertujuan untuk mengkaji komposisi geokimia enapan permukaan dan input antropogenik yang mungkin hadir dari penempatan bandar. Tekstur enapan adalah terdiri daripada liat dengan purata pecahan saiz liat sebanyak $45.15 \%$. Kelimpahan elemen utama secara tertib menurun adalah seperti berikut $\mathrm{SiO}_{2}>$ $\mathrm{Al}_{2} \mathrm{O}_{3}>\mathrm{K}_{2} \mathrm{O} \geq \mathrm{ClO}_{2} \geq \mathrm{Na}_{2} \mathrm{O}>\mathrm{MgO}>\mathrm{MnO}>\mathrm{ZnO}$. Dominasi $\mathrm{SiO}_{2}$ membayangkan terdapat perkaitan dengan aliran Sungai Pulai ke kawasan kajian. Kepekatan $\mathrm{ZnO}$ direkodkan beratus kali lebih tinggi daripada tahap semula jadi purata zink di dalam kerak bumi. Tahap Zn yang lebih tinggi mungkin diperolehi daripada gabungan input antropogenik dan proses geokimia semula jadi. Kelimpahan mineral mengikuti urutan berikut kuarza $>$ kaolinit $>$ muskovit $>$ smektit $>$ kalsit $>$ ilit. Smektit dikesan pada enapan di bahagian hulu sungai namun tiada di dalam enapan muara. Keadaan ini mungkin disebabkan oleh pengumpulan dan keamatan produk luluhawa. Dominasi kuarza di dalam sedimen pantai adalah disebabkan oleh proses luluhawa.
\end{abstract}

Kata kunci: tropika, enapan, elemen-elemen, mineral liat, Malaysia 


\section{Hasrizal et al: GEOCHEMISTRY AND CLAY MINERALS OF SURFACE SEDIMENTS OF SOUTHWESTERN JOHOR, MALAYSIA}

\section{Introduction}

Southwestern Johor has a unique environment due to the combination of different ecosystems (i.e. river, mangrove, estuary and beaches) and rapid development zone (i.e. Tanjung Pelepas Port, industrial area, oil terminal and urbanization). A report by ASEAN/US CRMP [1] stated that $\sim 80 \%$ of Johor land is formed by sedimentary, metasedimentary and igneous rocks of pre-quaternary while the remaining $20 \%$ is covered by unconsolidated to semi consolidated quaternary sediments. Rapid development in this area over the past two decades might have caused changes in elemental composition. Thus, there is a possibility that the sediment deposits in coastal areas of Southwestern Johor are derived from natural and/ or anthropogenic sources. In certain conditions, the elements in surface sediment are governed by their concentration, relative proportions from various sources, components and forcing mechanisms. Some reports indicated the significant role of grain size sediments in controlling the element's content in coastal area [2-4], and the enrichment of elements in fine-grained sediments is attributed to their adsorption capabilities and low contents of quartz [5]. Based on the previous reports, we consequently presume that the relationship between elements and grain size can be applied as the environmental indicator in the coastal area of Southwestern Johor. Recently, several environmental studies have been conducted in the coastal area of Southwestern Johor [6-10]. However, there have been no reports that focus on the distribution of sediment mineral contents and geochemical composition in surface sediment. Thus, this paper presented and discussed the abundance and distribution of major elements and clay minerals composition in surface sediment of the Southwestern Johor.

\section{Sample collection and preservation}

\section{Materials and Methods}

Table 1 shows the coordinates of sampling points in the study area. The surface sediment samples were collected from 20 stations at different ecosystems of the coastal area of Southwestern Johor (Figure 1) using the ponar grab. The samples were then put in labelled plastic bags and brought back to the laboratory for further analysis.

Table 1. Latitude and longitude of the sampling points in the study area

\begin{tabular}{lcc}
\hline Station & Latitude & Longitude \\
\hline 1 & $01^{\circ} 19.647^{\prime} \mathrm{N}$ & $103^{\circ} 26.180^{\prime} \mathrm{E}$ \\
2 & $01^{\circ} 19.419^{\prime} \mathrm{N}$ & $103^{\circ} 25.792^{\prime} \mathrm{E}$ \\
3 & $01^{\circ} 19.943^{\prime} \mathrm{N}$ & $103^{\circ} 26.352^{\prime} \mathrm{E}$ \\
4 & $01^{\circ} 20.206^{\prime} \mathrm{N}$ & $103^{\circ} 25.108^{\prime} \mathrm{E}$ \\
5 & $01^{\circ} 18.383^{\prime} \mathrm{N}$ & $103^{\circ} 25.222^{\prime} \mathrm{E}$ \\
6 & $01^{\circ} 18.895^{\prime} \mathrm{N}$ & $103^{\circ} 26.259^{\prime} \mathrm{E}$ \\
7 & $01^{\circ} 20.169^{\prime} \mathrm{N}$ & $103^{\circ} 25.517^{\prime} \mathrm{E}$ \\
8 & $01^{\circ} 20.040^{\prime} \mathrm{N}$ & $103^{\circ} 25.320^{\prime} \mathrm{E}$ \\
9 & $01^{\circ} 19.175^{\prime} \mathrm{N}$ & $103^{\circ} 32.482^{\prime} \mathrm{E}$ \\
10 & $01^{\circ} 21.758^{\prime} \mathrm{N}$ & $103^{\circ} 32.206^{\prime} \mathrm{E}$ \\
11 & $01^{\circ} 23.966^{\prime} \mathrm{N}$ & $103^{\circ} 32.146^{\prime} \mathrm{E}$ \\
12 & $01^{\circ} 26.492^{\prime} \mathrm{N}$ & $103^{\circ} 29.655^{\prime} \mathrm{E}$ \\
13 & $01^{\circ} 27.457^{\prime} \mathrm{N}$ & $103^{\circ} 33.188^{\prime} \mathrm{E}$ \\
14 & $01^{\circ} 22.604^{\prime} \mathrm{N}$ & $103^{\circ} 38.342^{\prime} \mathrm{E}$ \\
15 & $01^{\circ} 23.208^{\prime} \mathrm{N}$ & $103^{\circ} 38.743^{\prime} \mathrm{E}$ \\
16 & $01^{\circ} 20.636^{\prime} \mathrm{N}$ & $103^{\circ} 34.372^{\prime} \mathrm{E}$ \\
17 & $01^{\circ} 16.260^{\prime} \mathrm{N}$ & $103^{\circ} 30.960^{\prime} \mathrm{E}$ \\
18 & $01^{\circ} 15.608^{\prime} \mathrm{N}$ & $103^{\circ} 30.531^{\prime} \mathrm{E}$ \\
19 & $01^{\circ} 17.040^{\prime} \mathrm{N}$ & $103^{\circ} 28.734^{\prime} \mathrm{E}$ \\
20 & $01^{\circ} 16.980^{\prime} \mathrm{N}$ & $103^{\circ} 30.600^{\prime} \mathrm{E}$ \\
\hline
\end{tabular}




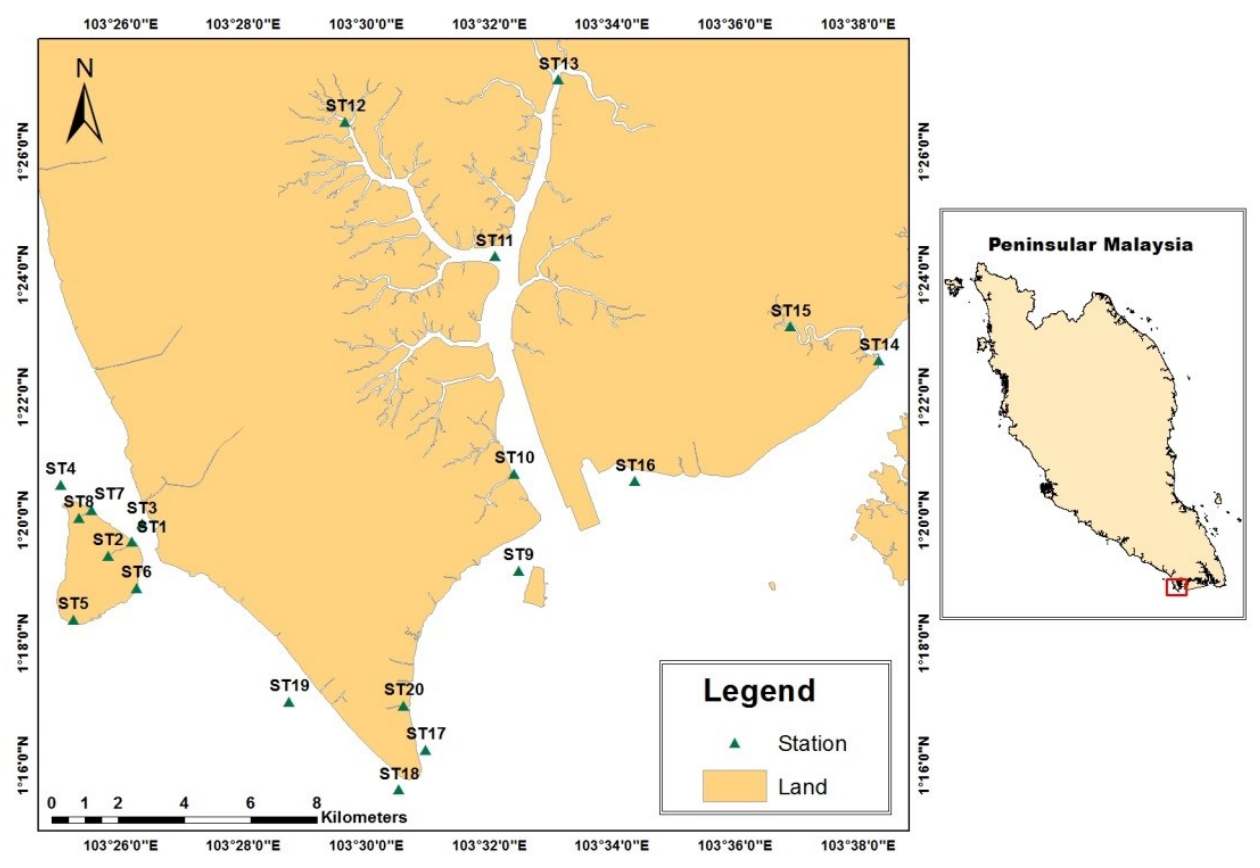

Figure 1. Location of sampling stations in the study area

\section{Analytical techniques}

Approximately $5 \mathrm{~g}$ of sediment samples were used in determining particle size. Homogenized samples were treated with $10 \mathrm{ml}$ calgon solution overnight and injected into the particle size analyzer MALVERN Mastersizer 2000. All data collected were subjected to statistical analysis using moment statistical method. The relative proportion of sand, silt and clay were determined using the textural triangle proposed by USDA [11]. The major oxide elements in sediment were analyzed by using scanning electron microscope-energy dispersive spectrometer (SEM-EDS). The samples were placed on the stub using double sided tape and coated with gold by Auto Fine Coater JFC 1600. The selected major oxide elements $\left(\mathrm{SiO}_{2}, \mathrm{Al}_{2} \mathrm{O}_{3}, \mathrm{Na}_{2} \mathrm{O}, \mathrm{MgO}, \mathrm{CaO}, \mathrm{K}_{2} \mathrm{O}, \mathrm{MnO}, \mathrm{ZnO}\right)$ were observed by using SEM model 6360 LA JOEL. Sediment samples for clay mineral analysis were dried in the oven $\left(<50{ }^{\circ} \mathrm{C}\right)$ and powdered using pestle mortar. The type of clay minerals present in the samples was analyzed using X-ray Diffractometer (XRD). The sample was placed on a glass slide and scanned for certain degrees using radiation of $\mathrm{Cu}-\mathrm{K} \alpha$ equipped with automatic divergent tilt. The Joint Committee on Powder Diffraction Standards (JCPDS) was used as a reference. Peaks produced from X-Ray Diffractogram enabled the determination of d-spacing which associated with the types of mineral.

\section{Results and Discussion}

Table 2 shows the percentage of sand, silt, clay and the textural class of sediments in the study area. The distribution patterns of sand, silt and clay are shown in Figure 2, 3 and 4, respectively. Most of the sediments in the study area can be classified as cohesive sediments where the size of sediments is less than $125 \mu \mathrm{m}$ in diameter and large surface area in relation to its mass. The high percentage of clay particles with the value $>50 \%$ was recorded at ST1, ST2, ST3, ST4, ST7, ST11, ST13 and ST17. The high percentage of sand with the value $>50 \%$ was found at ST6, ST10, ST12, ST15, ST16 and ST18. Only ST5 registered silt content more than 50\%. 


\section{Hasrizal et al: GEOCHEMISTRY AND CLAY MINERALS OF SURFACE SEDIMENTS OF SOUTHWESTERN JOHOR, MALAYSIA}

Table 2. Percentage of sand, silt and clay and textural classes of sediments in the study area

\begin{tabular}{lcccl}
\hline Station & Sand (\%) & Silt $(\%)$ & Clay $(\%)$ & Textural class \\
\hline 1 & 22.73 & 10.69 & 66.56 & Clay \\
2 & 27.83 & 8.16 & 63.98 & Clay \\
3 & 34.92 & 7.91 & 57.83 & Clay \\
4 & 37.98 & 6.50 & 55.52 & Clay \\
5 & 36.14 & 55.86 & 8.01 & Silt loam \\
6 & 54.09 & 6.91 & 39.02 & Sandy clay \\
7 & 32.07 & 7.90 & 60 & Clay \\
8 & 49.4 & 6.53 & 44.08 & Sandy clay \\
9 & 42.14 & 7.42 & 48.98 & Sandy clay \\
10 & 73.88 & 24.50 & 23.66 & Sandy clay loam \\
11 & 21.81 & 15.40 & 62.8 & Clay \\
12 & 61.1 & 4.15 & 37.74 & Sandy clay loam \\
13 & 21.09 & 15.83 & 63.09 & Clay \\
14 & 44.26 & 6.91 & 48.86 & Clay \\
15 & 51.02 & 5.89 & 43.1 & Sandy clay \\
16 & 63.47 & 7.87 & 28.67 & Sandy clay loam \\
17 & 36.9 & 8.01 & 55.1 & Clay \\
18 & 79.86 & 4.24 & 15.9 & Sandy Loam \\
19 & 48.52 & 5.94 & 45.55 & Sandy clay \\
20 & 37.22 & 8.63 & 54.18 & Clay \\
\hline
\end{tabular}

The relative proportion of textural classes of sediment was based on the percentage of sand, silt and clay (Table 2). Generally, the southwestern coastal area of Johor is dominated with clay (ST1, ST2, ST3, ST4, ST7, ST11, ST13, ST14, ST17 and ST20), sandy clay (ST6, ST8, ST9, ST15 and ST19), sandy clay loam (ST10, ST12 and ST16), sandy loam (ST18) and silt loam (ST5). Coarse sediment is dominant in two areas namely Tanjung Pelepas Port (ST10 and ST16), and the coastal area between south Pulau Kukup (ST 5) and Tanjung Piai National Park (ST18). The prevalence of coarse sediment in Tanjung Pelepas Port might be due to the wave action created by shipping activities and the deepening process of the port through dredging activities. Both processes will destabilize the composition of sediment in the port area and it will be much easier for them to be transported out in any condition involving increasing water forces. Meanwhile, finer sediment tends to accumulate in the upstream of Sungai Pulai (ST11 and ST13), northern part of Pulau Kukup (ST1, ST3 and ST7) and in front of Tanjung Piai town (ST19 and ST20). We assume that the accumulation of finer sediment had occurred due to the low energy environment. This will offer a suitable condition for the deposition of fine-grain sediment in those three areas compared to Tanjung Pelapas Port and the coastal area between south Pulau Kukup and Tanjung Piai National Park. Consequently, it is hypothesized that the different distribution pattern of sand, silt, clay and textural classes of sediment are relatively due to the different forces of water energy in this environment. 


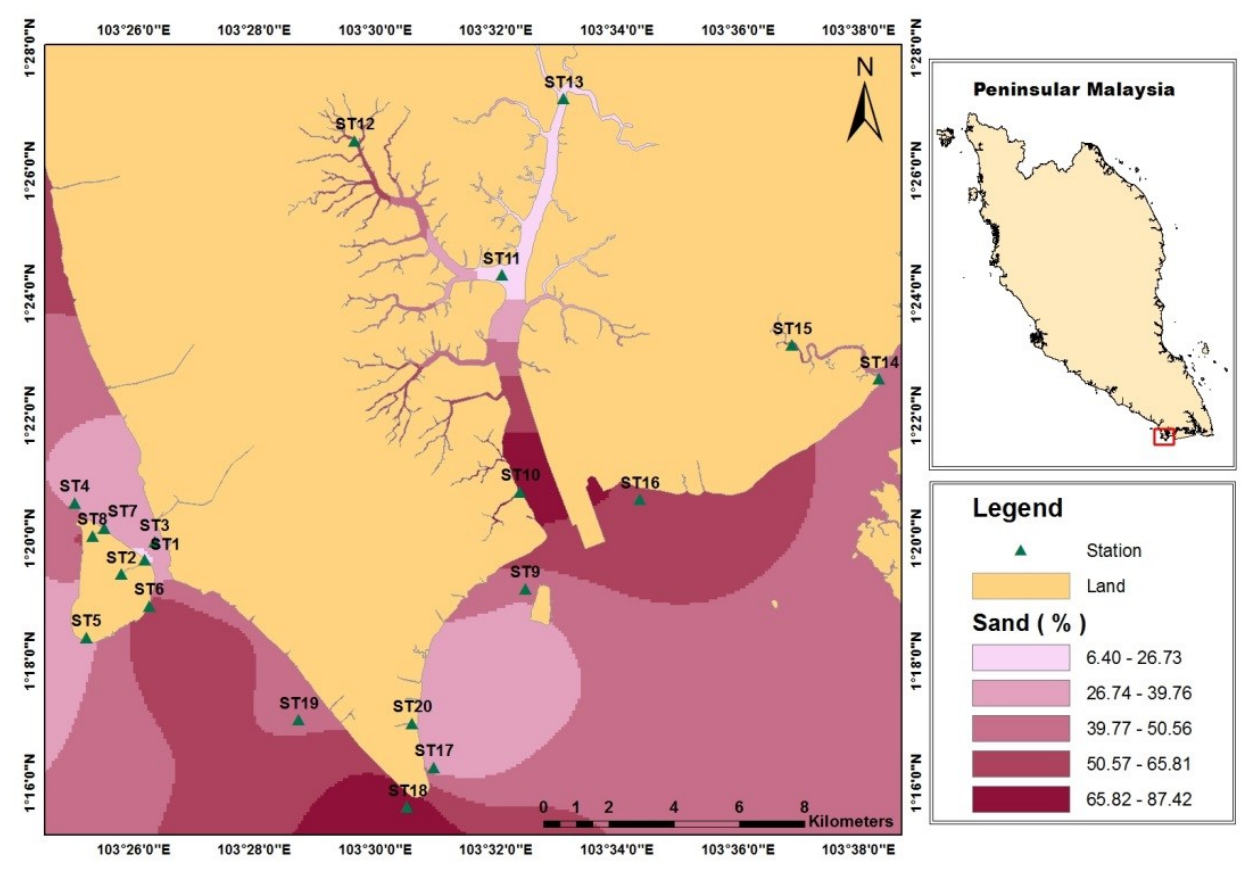

Figure 2. Distribution patterns of sand in the study area

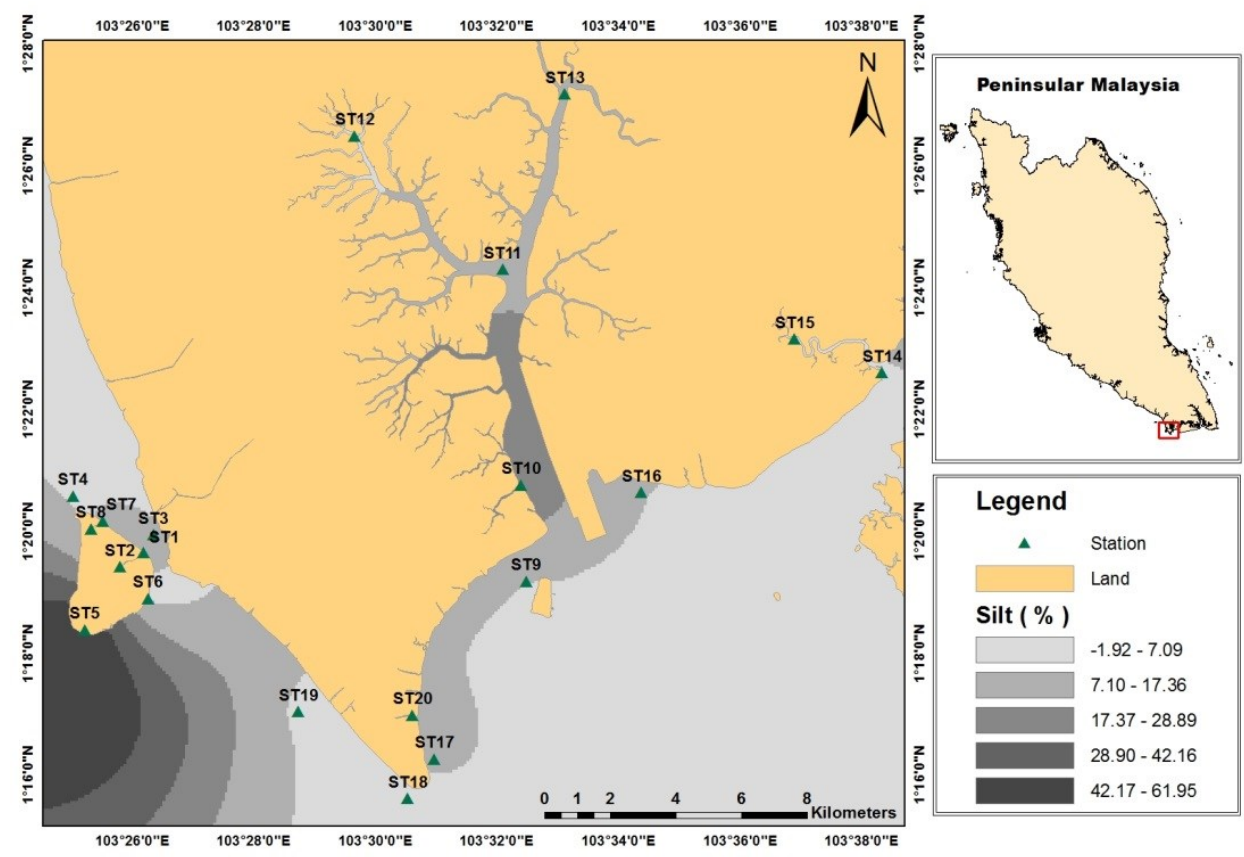

Figure 3. Distribution patterns of silt in the study area 


\section{Hasrizal et al: GEOCHEMISTRY AND CLAY MINERALS OF SURFACE SEDIMENTS OF SOUTHWESTERN JOHOR, MALAYSIA}

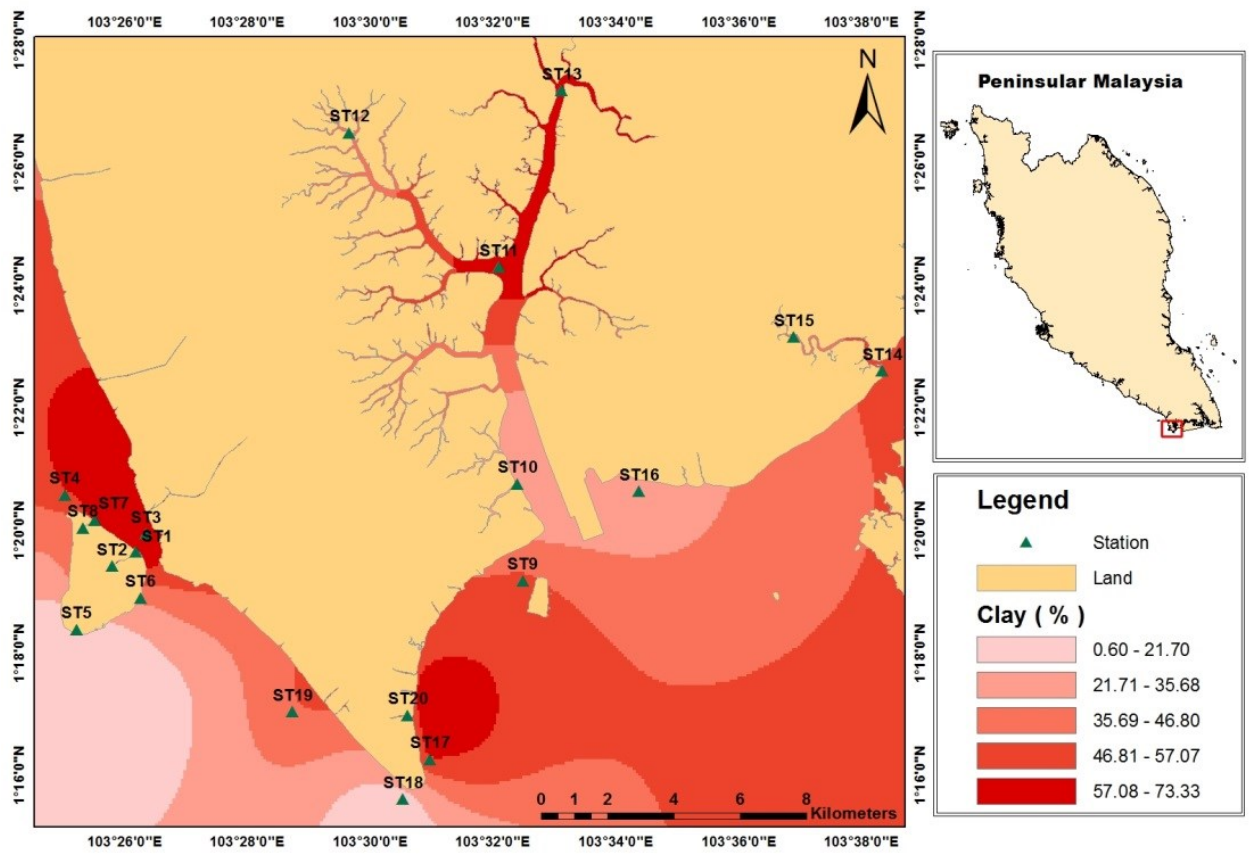

Figure 4. Distribution patterns of $\%$ clay in the study area

\section{Element oxides}

Table 3 shows the percentage of element oxides in the study area. The dominant element oxides found in the study area are $\mathrm{SiO}_{2}(59.62 \%)$ followed by $\mathrm{Al}_{2} \mathrm{O}_{3}(12.49 \%)$. The rest of the element oxides such as $\mathrm{K}_{2} \mathrm{O}, \mathrm{ClO}_{2}, \mathrm{MgO}_{2}$, $\mathrm{MnO}_{2}$ and $\mathrm{ZnO}_{2}$ are present in trace amounts. The dominance of $\mathrm{SiO}_{2}$ indicates that the area is highly siliceous [12]. The higher percentages of $\mathrm{SiO}_{2}$ are found at ST6 (75.43\%) and ST5 $(72.47 \%)$, which show that these stations are most siliceous compared to the other of stations. The dominance of quartz might be due to the weathering product of granite, which is the dominant rock discovered in southern Peninsular Malaysia [13]. It is assumed that the quartz becomes the most resistant mineral in the coastal area of Southwestern Johor due to high temperatures and annual rainfall of tropical climatic conditions thus leading to the presence of high $\mathrm{SiO}_{2}$ content.

The second most abundant element oxide is $\mathrm{Al}_{2} \mathrm{O}_{3}$ (corundrum) formed from igneous rock. The high content of this element at ST12 might be due to high-energy of water in upstream that erodes, transports and deposits sediments into the mangrove area. Wayne et al. [14] suggest that $\mathrm{Al}_{2} \mathrm{O}_{3}$ in certain environments are strongly influenced by aeolian input driven by wind activity and higher energy transport. The formation of corundum also occurs during hydrothermal alteration of volcanic and ultramafic rocks, under regional metamorphism of alumina-rich clays and bauxites, and in alkaline magmas that are alumina-supersaturated and silica-undersaturated [15].

The other oxide elements present in surface sediments of the study area were $\mathrm{K}_{2} \mathrm{O}(2.19 \%), \mathrm{ClO}_{2}(2.12 \%), \mathrm{Na}_{2} \mathrm{O}$ $(2.11 \%)$ and $\mathrm{MgO}(1.90 \%) . \mathrm{K}_{2} \mathrm{O}$ is a major element oxide present in trace amounts in the study area. This might be due to the sediment deposits originating from the dissolution of $\mathrm{K}$-feldspar and mica [16]. Manganese oxide is a minor component of sediment with a value below $0.5 \%$ of dry weight and exists in the sediment as carbonate phase and oxi-hydroxide phase. The average content of $\mathrm{MnO}$ in the study area was $0.96 \%$. This value is about one-fold lower than $\mathrm{K}_{2} \mathrm{O}, \mathrm{ClO}_{2}, \mathrm{Na}_{2} \mathrm{O}$ and $\mathrm{MgO}$. 
Table 3. Percentage of element oxides in sediments of the study area

\begin{tabular}{lcccccccc}
\hline Station & $\mathbf{S i O}_{2}$ & $\mathbf{A l}_{\mathbf{2}} \mathbf{O}_{\mathbf{3}}$ & $\mathbf{K}_{\mathbf{2}} \mathbf{O}$ & $\mathbf{C l O}_{\mathbf{2}}$ & $\mathbf{N a}_{\mathbf{2}} \mathbf{O}$ & $\mathbf{M g O}$ & $\mathbf{M n O}$ & $\mathbf{Z n O}$ \\
\hline 1 & 55.16 & 8.64 & 1.67 & 2.64 & 1.15 & 1.2 & 0.9 & 1.43 \\
2 & 56.26 & 9.63 & 1.62 & 2.7 & 5.2 & 1.02 & 0.84 & 0.6 \\
3 & 57.18 & 8.91 & 3.14 & 1.65 & 1.25 & 1.14 & 1.23 & 0.37 \\
4 & 59.27 & 9.23 & 3.22 & 2.07 & 1.64 & 1.26 & 0.64 & 0.54 \\
5 & 72.47 & 8.71 & 2.51 & 2.72 & 7.31 & 1.43 & 0.4 & 1.07 \\
6 & 75.43 & 19.51 & 1.74 & 1.67 & 4.12 & 2.46 & 0.87 & 0.51 \\
7 & 59.22 & 9.31 & 1.84 & 1.86 & 4.32 & 2.44 & 0.98 & 0.42 \\
8 & 60.43 & 20.45 & 1.67 & 1.48 & 1.7 & 2.51 & 1.15 & 0.79 \\
9 & 55.82 & 9.01 & 1.79 & 1.94 & 1.4 & 2.34 & 1.43 & 0.61 \\
10 & 61.24 & 9.94 & 1.83 & 1.87 & 1.89 & 1.35 & 0.86 & 0.55 \\
11 & 55.47 & 18.6 & 2.65 & 3.02 & 2.03 & 1.48 & 0.84 & 0.58 \\
12 & 58.87 & 24.86 & 2.74 & 2.69 & 1.46 & 1.64 & 0.89 & 0.57 \\
13 & 57.24 & 22.63 & 3.1 & 2.51 & 0.83 & 2.12 & 0.82 & 0.59 \\
14 & 53.14 & 16.71 & 1.49 & 2.64 & 1.45 & 2.21 & 0.74 & 0.5 \\
15 & 60.4 & 16.04 & 1.69 & 1.95 & 0.69 & 2.46 & 1.19 & 1.13 \\
16 & 62.04 & 8.73 & 2.47 & 1.92 & 1.79 & 2.01 & 0.79 & 0.50 \\
17 & 57.3 & 8.31 & 2.91 & 1.11 & 0.61 & 2.35 & 1.29 & 1.35 \\
18 & 57.84 & 5.04 & 2.46 & 2.38 & 1.64 & 2.45 & 1.83 & 0.99 \\
19 & 60.15 & 10.3 & 1.57 & 2.26 & 1.43 & 2.37 & 0.63 & 0.82 \\
20 & 53.72 & 8.33 & 1.86 & 1.43 & 1.65 & 2.11 & 0.76 & 0.46 \\
\hline Average & 59.62 & 12.49 & 2.19 & 2.12 & 2.11 & 1.90 & 0.96 & 0.70 \\
SD $( \pm)$ & 5.48 & 5.68 & 0.58 & 0.51 & 1.70 & 0.53 & 0.32 & 0.32 \\
\hline & & & & & & & &
\end{tabular}

The lowest abundant element oxide in this environment is $\mathrm{ZnO}$. However, the content of this element oxide is relatively higher compared to the earth's crustal values. The concentration of $\mathrm{ZnO}(\sim 0.7 \%)$ registered a hundred times higher value than the average natural zinc in the earth's crust (70 ppm). In the manufacturing industry, $\mathrm{ZnO}$ is widely used as an additive in numerous materials and products including rubbers, plastics, ceramics, glass, cement and lubricants [17]. Thus, it is plausible that the anthropogenic input might be mixed with the natural zinc-origin products, causing an enrichment of $\mathrm{ZnO}$ in this environment.

SEM imagery and major element peaks clearly show the differences in grain particle shapes and element contents between downstream (Figure 5a) and upstream (Figure 5b) areas. Downstream sediments are characterized with sorted and more rounded angularity grain, higher content of silicon and aluminum. On the other hand, the upstream sediment recorded was poorly sorted and angular type of grain. There is a possibility that high-energy water especially during monsoon season sorted and smoothed the edges of grain particle in the transportation process of sediment from upstream to downstream. 

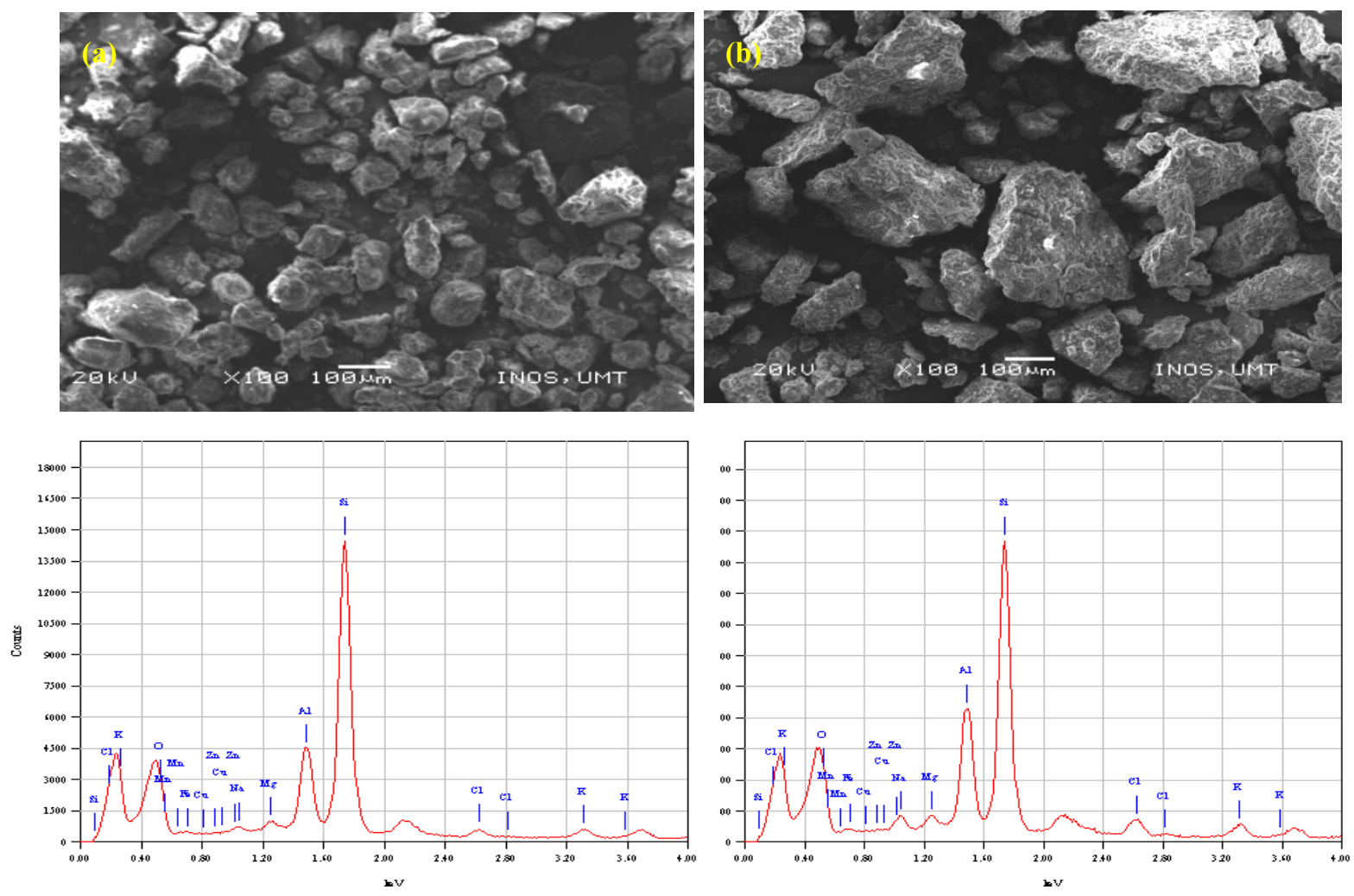

Figure 5. An example of SEM-EDS imagery and major element peaks of (a) downstream and (b) upstream area

\section{Clay minerals}

Table 4 shows the clay minerals present in the study area. Quartz (Figure 6a) is the dominant mineral found in most of the stations (ST1, ST2, ST3, ST8, ST10, ST11, ST12, ST14, ST15, ST19 and ST20) and frequent at ST4, ST6, ST7, ST13, ST16, and ST17, while few at ST5, ST9 and ST18. The second most abundant clay mineral is kaolinite (Figure 6b) which is dominant at ST1 and ST13. Kaolinite is present at station ST3 and ST6, in moderate amounts whereas exists in small amounts at other remaining station. Hurst [18] proposed that the distribution of kaolinite is often associated with the exfoliation and change in content of mica minerals in sediments. This might be due to the influence of weathering. Pehlivanoglou et al. [4] suggested that low distribution of kaolinite was due to unfavorable climatic conditions as well as physicochemical factors including sediment origin, rapid transportation and deposition process at the sampling station. Presence of kaolinite as a dominant clay mineral indicated maturity of the sediments and the weathering stage. The predominance of kaolinite indicated humid periods that lead to intensive leaching and chemical weathering [19].

The third abundant mineral in the surface sediment is muscovite (Figure 6c). This clay mineral is present at ST10 and ST11 in moderate amount, while ST1, ST8, ST12 and ST13 show the presence of muscovite in small amounts. High content of muscovite can be found at Sungai Pulai (ST10 and ST11), respectively. According to Rothwell [20], muscovite was the second most stable primary mineral after quartz. Muscovite is usually found in coarsegrained igneous rock and intermediate metamorphic rock [21]. The existence of this clay mineral in the sediments indicated that the sediments are still young [22].

Only four stations had shown the presence of illite with ST13 showing moderate amounts while ST8, ST15 and ST20 show small amounts of illite. On the other hand, ST15 is the only station showing moderate content of smectite in the study area. The presence of smectite in small amounts at ST1, ST2 and ST13 might be influenced by 
the accumulation and intensity of weathering products. El-Attar et al. [23] found that smectite exists on the surface layer of sediment by the mixing of aeolian inputs from the plateau.

Table 4. The presence of clay minerals in sediments of the study area

\begin{tabular}{lcccccc}
\hline \multirow{2}{*}{ Station } & \multicolumn{5}{c}{ Clay Minerals } \\
\cline { 2 - 7 } & Quartz & Calcite & Smectite & Illite & Kaolinite & Muscovite \\
\hline 1 & +++ & + & + & - & +++ & + \\
2 & +++ & - & + & - & + & - \\
3 & +++ & - & - & - & ++ & - \\
4 & ++ & - & - & - & + & - \\
5 & + & - & - & - & + & - \\
6 & ++ & - & - & - & ++ & - \\
7 & ++ & - & - & - & + & - \\
8 & +++ & - & - & + & + & + \\
9 & + & - & - & - & + & - \\
10 & +++ & - & - & - & ++ & ++ \\
11 & +++ & - & - & - & + & ++ \\
12 & +++ & - & - & - & + & + \\
13 & ++ & + & + & ++ & +++ & + \\
14 & +++ & + & - & - & + & - \\
15 & +++ & - & ++ & + & + & - \\
16 & ++ & - & - & - & + & - \\
17 & ++ & - & - & - & + & - \\
18 & + & - & - & - & + & - \\
19 & +++ & - & - & - & + & - \\
20 & +++ & - & - & + & + & - \\
\hline
\end{tabular}

+++ Mineral present in large amount (dominant)

++ Mineral present in moderate amount (frequent)

$+\quad$ Mineral present in small amount (few)

- Mineral not present



\section{Hasrizal et al: GEOCHEMISTRY AND CLAY MINERALS OF SURFACE SEDIMENTS OF SOUTHWESTERN JOHOR, MALAYSIA}

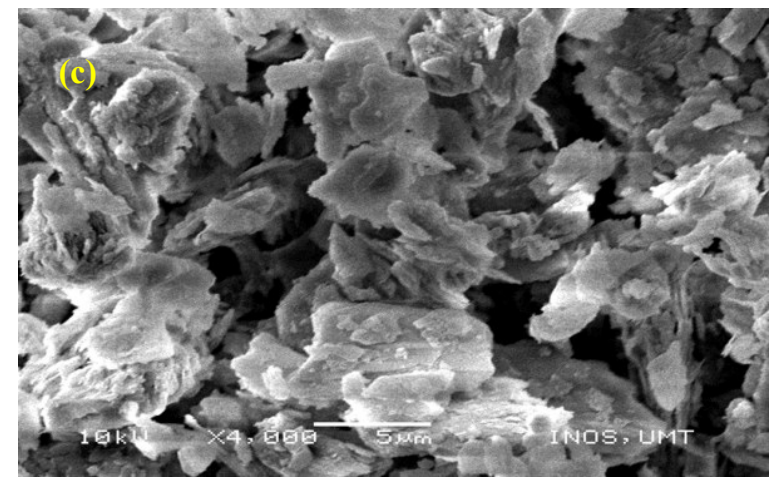

Figure 6. Morphological features of clay minerals found in the study area (a) quartz (b) kaolinite and (c) muscovite

\section{Conclusion}

The mean concentrations of studied element oxides in decreasing order is as follows $\mathrm{SiO}_{2}>\mathrm{Al}_{2} \mathrm{O}_{3}>\mathrm{K}_{2} \mathrm{O} \geq \mathrm{ClO}_{2} \geq$ $\mathrm{Na}_{2} \mathrm{O}>\mathrm{MgO}>\mathrm{MnO}>\mathrm{ZnO}$. The presence of quartz as the dominant mineral in this tropical environment is consistent with $\mathrm{SiO}_{2}$ as the most abundant major element oxide. The abundance of kaolinite compared to other clay minerals indicated the advance-weathering stage and reflection of granite as the major rock type in the area. The higher level of $\mathrm{ZnO}$ as compared to the earth's crustal value is associated with the combination of anthropogenic input, and natural geological and geochemical processes. The change in grain surface morphology and sorting from the upstream to the downstream show the intensity of sediment transport processes.

\section{Acknowledgement}

This research was funded by the Ministry of Science, Technology and Innovation through e-science grants no 0401-12-SF0113. The authors wish to express their gratitude to the staff of Oceanography Laboratory, School of Marine and Environmental Science and Institute of Oceanography and Environment (INOS) for their assistance and hospitality throughout the sampling and analytical period.

\section{References}

1. Association of Southeast Asian National United States Coastal Resources Management Project (ASEAN/US CRMP). (1991). The coastal environmental profile of South Johore, Malaysia. ICLARM Technical Report 24: $1-65$.

2. Abdullah, N. A., Shazili, N. A. M., Yaacob, R. and Kamaruzzaman, Y. (2014). Grain size and metallic trace element contents in sediments of Kemaman Coast, Terengganu, Malaysia, South China Sea. Journal of Earth Science and Engineering, 4: $80-87$.

3. Kamaruzzaman, Y., Mohd Yusuf, N., Shazili N. A. M. and Saad, S. (2011). Heavy metal concentration in the surface sediment of Tanjung Lumpur mangrove forest, Kuantan, Malaysia. Sains Malaysiana, 40(2): 89 - 92.

4. Pehlivanoglou, K., Trontsios, G. and Tsirambides, A. (2004). Grain size distribution, clay mineralogy and chemistry of bottom sediments from the outer Thermaikos Gulf, Aegean Sea, Greece. Mediterranean Marine Science, 5 (1): $43-53$.

5. Zhou, D., Yuan-Bo, L. and Cheng-Kui, Z. (1994). Oceanology of China Seas. Springer-Science and Business Media, Dorrecht.

6. Yusoff, A. H., Zulkifli, S. Z., Ismail, A. and Mohamed, C. A. R. (2015). Vertical trend of trace metals deposition in sediment core off Tanjung Pelepas Harbour, Malaysia. Procedia Environmental Sciences, $30: 211$ $-216$.

7. Zulkifli, S. Z., Mohamat-Yusuff, F., Ismail, A., Aziz, A. Sabuti, A. A. and Mohamed, C. A. R. (2015). Status of heavy metals in surface sediments of the western part of the Johor Straits using a sediment quality guideline. World Journal of Fish and Marine Sciences, 7 (3): 214 - 220. 
8. Guan, W. S., Ghaffar, M. A., Ali, M. M. and Cob, Z. C. (2014). The Polychaeta (Annelida) communities of the Merambong and Tanjung Adang Shoals, Malaysia, and its relationship with the environmental variables. Malayan Nature Journal, 66: 168 - 183.

9. Sabri, S., Said, M. I. M., Azman, S., Muda, K., Kassim, M. A. M. and Salmiati (2012). Copper in water, sediment and Strombus Canarium at South Western Coast of Peninsular Malaysia. International Journal of Environmental Science and Development, 3(3): 217 - 219.

10. Azlan, N. I. and Othman, R. (2009). Monitoring of mangrove area using remote sensing toward shoreline protection. GIS Ostrava, 1:25-28.

11. US Department of Agriculture (USDA). (1987). Agricultural resources: Cropland, water and conservation situation and outlook report. AR-Econ. Res. Serv. Washington, D.C.: pp. 439.

12. Abdullah, N. A., Yaakob, R., Ahmad, S., Chung, M. K. and So, A. N. (2007). Major elements and oxides of the South China Sea surface sediments off Johor Coasts. Journal of Sustainability Science and Management, 2(1): $79-85$.

13. Abad, S. N. A. K. S., Mohamad, E. T. and Komoo, I. (2014). Dominant weathering profiles of granite in Southern Peninsular Malaysia. Engineering Geology, 183: $208-215$.

14. Wayne, D. R, Fesha, I. G., Shaw, J. N., Wood, C. W., Feng, Y., Norfleet, M. L. and Van Santen. E. (2002). Land use effects on soil quality parameters for identical soil taxa. In Van Santen, E. (ed.) Southern Conservation Tillage Conference for Sustainable Agriculture, Auburn, Alabama. 24-26 June 2002. Alabama Agricultural Experiment Station and Auburn University: pp. 233 - 238.

15. Wenk, H-R. and Bulakh, A. (2004). Minerals their constitution and origin. Cambridge University Press. pp. 635.

16. Eberl, D. D. (1993). Three zones for illite formation during burial diagenesis and metamorphism. Clays \& Clay Minerals, 41: $26-37$.

17. Battez, H. A., Gonzalez, R., Viesca, J., Fernandez, J., Diazfernandez, J., MacHado, A., Chou, R. and Riba, J. (2008). $\mathrm{CuO}, \mathrm{ZrO}_{2}$ and $\mathrm{ZnO}$ nanoparticles as antiwear additive in oil lubricants. Wear, 265 (3-4): $422-428$.

18. Hurst, A. (1999). Textural and geochemical micro-analysis in the interpretation of clay mineral characteristics: Lessons from sandstone hydrocarbon reservoirs. Clay Minerals, 34(1):137 - 149.

19. Singer, A. (1984). The paleoclimatic interpretation of clay minerals in sediments - A review. Earth-Science Review, 21: $251-293$.

20. Rothwell, R. G. (1989). Minerals and mineraloids in marine sediments: An optical guide. Elsevier Applied Science, London: pp. 279.

21. Fanning D.S., Keramidas, V.Z and El-Desoky, M.A. (1989). In: Minerals in soil environments, $2^{\text {nd }}$ Edition: pp. $551-634$.

22. Tribble, J. S. and Wilkens, R. H. (1999). Mineralogy and microfabric of sediment from the Western Mediterranean Sea. Proceedings of the Ocean Drilling Program, Scientific Results, 161: 99 - 110.

23. El-Attar, H. A., Jackson, M. L. and Volk, V.V. (1972). Fluorine loss from silicates on ignition. American Mineralogist, 57: 246 - 452. 